\title{
Pemanfaatan Website Pemasaran Bagi Pelaku Usaha Kerajinan Anyam Mendong di Kecamatan Rajapolah Kabupaten Tasikmalaya
}

\author{
Suparman Ali ${ }^{*}$, Feby Inggriyani ${ }^{1}$, Depy Muhamad Fauzy ${ }^{2}$ \\ ${ }^{1}$ Universitas Pasundan, Jl. Dr. Setiabudi No. 193 Bandung 40154 \\ ${ }^{2}$ Universitas Perjuangan, Jl. Pembela Tanah Air 177, Kahuripan, Tasikmalaya \\ *Email koresponden: suparmanali@unpas.ac.id
}

\begin{abstract}
Abstrak
Tujuan dari kegiatan PKM (Program Kemitraan Masyarakat) pada pelatihan pemanfaatan website pamasaran yaitu untuk membantu kelompok usaha kerajinan anyam mendong dalam pengembangan bisnis mereka agar lebih maju dan sejahtera di Kecamatan Rajapolah Kabupaten Tasikmalaya. Permasalahan kedua mitra yaitu UKM Saputra Handycraft dan UKM Risma Handycraft memiliki keterbatasan sistem pemasaran yang masih tradisional sehingga omzet penjualan dan nilai jual produk masih rendah. Oleh karena itu, untuk meningkatkan penjualan dilakukan dengan melakukan pelatihan dalam memperluas pemasaran dengan media internet yaitu website. Metode pelaksanaan adalah pelatihan. Hasil pelatihan pengelolaan website pemasaran yaitu dibuatnya website untuk aplikasi marketplace bagi pelaku usaha dalam mempromosikan produk kerajinan anyam mendong dan pelaku usaha dapat mengetahui bangaimana langkah-langkah stategis dalam pemasaran melalui website serta mengetahui pemanfaatan website dalam pemasaran. Simpulan kegiatan pelatihan yaitu peserta antusias dalam mengikuti pelatihan dan adanya peningkatkan pengetahuan serta kemampuannya dalam menggunakan website pemasaran.
\end{abstract}

Kata kunci: pelatihan, PKM, website pemasaran

\begin{abstract}
The purpose of the Community Partnership Program (PKM) activities in training the use of the website marketing is to help the mendong weaving craft group in developing their business so that they are more advanced and prosperous in Rajapolah District Tasikmalaya Regency. The problems of the two partners namely UKM Saputra Handycraft and UKM Risma Handicraft have limited traditional marketing systems so that sales turnover and product selling value are still low. Therefore, to increase sales is done by training in expanding marketing with internet media, namely the website. The method of implementation is training. The results of the training on marketing website management are the creation of a website for marketplace applications for business people in promoting Mendong woven craft products and business people can know how strategic steps are in marketing through the website and knowing the use of the website in marketing. The conclusions of the training activities participants were enthusiastic in participating in the training and there was an increase in their knowledge and ability to use website marketing.
\end{abstract}

Keywords: training, PKM, website marketing

Format Sitasi: Ali S., Inggriyani F. \& Pauzy D.M. (2018). Pelatihan Pemanfaatan Website Pemasaran Bagi Pelaku Usaha Kerajinan Anyam Mendong di Kecamatan Rajapolah Kabupaten Tasikmalaya. Jurnal SOLMA, 7(2), 193-199. Doi: http://dx.doi.org/10.29405/solma.v7i2.2009.

Diterima: 22 September 2018 | Revisi: 21 Oktober 2018 | Dipublikasikan: 30 Oktober 2018 


\section{PENDAHULUAN}

UKM di Indonesia menjadi magnet utama pada perekonomian saat ini yang membuat pemerintah setempat harus dapat membuat sektor UKM menjadi lebih bergairah dan mampu berkompetisi dengan UKM yang lainnya. Di Jawa Barat terdapat salah satu UKM yang menghasilkan kerajinan unik, menarik dan berkualitas dari bahan anyam mendong yang terletak di Rajapolah Kabupaten Tasikmalaya dan memiliki citra, ramah lingkungan serta daya saing yang tinggi.

Berdasarkan hasil observasi dan wawancara, analisis situasi di UKM Saputra Handycraft dan UKM Risma Handycraft ini adalah UKM ini memiliki kendala, salah satunya dalam pemasaran hasil produki kerajinan. Pelaku usaha hanya memasarkan hasil produknya secara konvensional yanga rtinya hanya menjual di sekitar rumah mereka dan hanya membuat kalau ada pesanan saja. Dengan demikian berdampak pada omset penjualan handicraft yang tidak stabil. Padahal salah satu kunci keberhasilan UKM adalah adalah tersedianya pasar yang luas bagi peningkatan produksi usahanya. Hal ini sesuai dengan pendapat Irrubai, dkk. (2016) yang menjelaskan bahwa beberapa industri rumah tangga dalam bentuk UKM masih memiliki keterbatasan dalam aspek kualitas, khususnya tentang pemasaran dan hal ini berdampak pada nilai pendapatan yang kurang.

Chabib (2018), menjelaskan bahwa pemasaran didefinisikan sebagai aliran produk yang dihasilkan secara fisis dan ekonomi dari produsen melalui pedagang perantara ke konsumen yang membutuhkan. Dengan demikian, melalui pemasaran yang efektif dan produktif akan menghasilkan keberhasilan di dalam usaha dan berdampak pada peningkatan omset usahanya sehingga masyarakat pelaku usaha dan lingkungan disekitarnya sejahtera. Kelemahan mendasar yang dihadapi UKM dalam bidang pemasaran adalah orientasi pasar yang rendah, lemah di dalam persaingan yang kompleks dan tajam serta tidak memadainya infrastruktur pemasaran yang dimiliki (Susanto, Supriyanto, Purwatiningtyas, 2015). Oleh karena itu, dalam menghadapi mekanisme pasar yang makin terbuka dan kompetitif, penguasaan pasar merupakan prasyarat untuk meningkatkan daya saing (Adiono, 2011). Hal ini disesabkan karena kesuksesan yang dicapai suatu usaha bisa dilihat dari pangsa pasar yang dimilikinya.

Semakin luas area cakupan pemasaran produk, kesempatan untuk mendapatkan keuntungan semakin besar dan permintaan produk juga akan terus mengalir. Jika hal ini bisa tercapai, maka suatu usaha atau bisnis dapat bertahan dalam persaingan dengan keberlangsungan usaha terjamin. Namun, tidak semua pengelola pengusaha mampu 
bersaing dan mencapai pangsa pasar, masih ada yang belum dapat memperluas dan mencapai pangsa pasar yang baru. Hal ini disebabkan karena keterbatasan kemampuan dan modal yang dimiliki, serta SDM menjadi salah satu kendala yang dihadapi karena masih belum handal dan belum memiliki hard skill yang mantap (Radjab dll, hlm.292). Padahal, apabila pemasaran produk dapat meluas maka akan dapat meningkatkan daya beli sehingga otomatis produksi meningkat dan hal ini akan membawa kesejahteraan masyarakat pelaku UKM tersebut. Hal tersebutlah yang membuat pelaku UKM menginginkan pemasarannya meluas ke daerah-daerah lain, baik nasional maupun internasioal, tetapi karena terkendala dana untuk promosi dan kesulitan dalam mendapatkan modal pengembangan usaha, maka keinginan tersebut belum dapat terwujud sampai saat ini.

Berdasarkan hal tersebut, maka tim pengabdian kepada masyarakat melakukan beberapa hal untuk membantu mengatasi permasalahan tersebut dengan cara menginisiasi pembuatan toko online melalui website pemasaran dan dengan diberikannya pelatihan dalam pengelolaan website serta memberikan pemahaman mengenai pentingnya mengoptimalkan pemasaran melalui website sebagai media pemasaran untuk perluasan jangkauan pasar baik secara nasional maupun internasional.

Tujuan pelaksanaan program pengabdian kepada masyarakat ini adalah menginisiasi pembuatan toko online melalui website pemasaran dan pelaku usaha dapat menjual hasil usahanya di media website sehingga memudahkan konsumen untuk membeli. Sedangkan manfaat dari pelaksanaan ini adalah terbentuknya toko online Anyam Mendong berbasis website dan website tersebut dapat digunakan sebagai promosi.

\section{MASALAH}

Permasalahan yang diangkat untuk menyelesaikan kondisi mitra yaitu kedua UKM memiliki kendala didalam pemasaran. Hal ini dikarenakan karena kurangnya mitra didalam memasarkan produknya dan tidak adanya media promosi untuk pemasaran. Selain itu, modal dan motivasi dari pelaku usaha pun rendah dibuktikan dengan hanya membuat hasil kerajinan apabila ada pesanan saja. Oleh karena itu, tim pengabdian melakukan pelatihan pemanfaatan website pemasaran kepada pelaku usaha anyam mendong sehingga memudahkan konsumen didalam membeli dan memudahkan pelaku usaha di dalam memasarkan hasil produksinya. Selain itu, dapat meningkatkan pengetahuan dan pemahaman pelaku usaha di dalam melakukan pemasaran hasil produksinya. 


\section{METODE PELAKSANAAN}

Pelaksanaan kegiatan pelatihan pemanfaatan website pemasaran dilaksanakan pada tanggal 28 Mei 2018. Kegiatan ini dilaksanakan di Madrasah Al Furqon Desa Ciberkah Kecamatan Rajapolah Kabupaten Tasikmalaya. Peserta pelatihan terdiri dari dua UKM yaitu UKM Saputra Handycraft dan UKM Risma Handycraft. Jumlah peserta terdiri dari 16 orang yang bekerja sebagai karyawan maupun pemilik usaha dari kedua UKM. Pelatihan pendampingan website pemasaran melalui toko online dilakukan mulai dari pembuatan site map dan web untuk UKM. Persiapan ini dilakukan selama satu bulan dalam menentukan domain/website, desain web dan persiapan lainnya. Peralatan yang digunakan dalam pelatihan antara lain yaitu laptop, jaringan internet, listrik, meja, computer, mouse dan peralatan penunjang lainnya.

Pelaksaan program pengabdian kepada masyarakat dilakukan dengan beberapa tahapan yaitu 1) Menginformasikan kegiatan kepada pengelola UKM, 2) Mengumpulkan data untuk toko online seperti deskripsi mengenai UKM, deskripsi produk/potensi yang dibuat dan dijual, keunggulan produk yang dibuat dan dijual dan lain-lain. 3) Perancangan website berdasarkan data-data yang telah dikumpulkan, 4) Hasil rancangan toko online melalui desain website sesuai dengan kebutuhan dan harapan mitra, 5) Pelatihan pengelolaan bagi pengelola website serta penyerahan website kepada mitra.

Metode dalam pelaksanaan pengabdian yaitu pelatihan. Pelatihan diawali dengan menyampaikan teori tentang teknologi informasi. Materi yang disampaikan meliputi cara pemanfaatan media online untuk pemasaran, cara pemasaran online dengan website, pelatihan pemasaran meliputi pelatihan internet marketing dan promosi melalui jejaring sosial media. Pada kegiatan ini dilakukan dengan pembuatan blogspot untuk masing-masing UKM mitra guna meningkatkan jangkauan pemasaran, dilatih dalam menuangkan ide bisnis dalam media online, dan bagaimana membuat media pemasaran secara online. Selain itu, dilakukan praktik setelah pengelola usaha diberikan materi tentang media online. Ketika kegiatan praktik, peserta pelatihan mengoperasikan handphone/laptop.

Evaluasi pelatihan diukur berdasarkan konsep penerimaan pengelola usaha anyam mendong dalam memanfaatkan media online melalui website pemasaran. Konsep yang digunakan adalah e-bisnis. Pencapaian konsep ini adalah seberapa besar minat peserta pelatihan untuk memanfaatkan media online melalui website. Untuk itu, akan dilakukan evaluasi pretest dan posttest untuk mengukur keberhasilan kegiatan pelatihan yang dilakukan meliputi, 1) Mengidentifikasi kemampuan peserta secara individu terhadap 
pemanfaatan media online dengan diberikan pertanyaan untuk mengetahui seberapa jauh pemahaman terhadap media online sebelum mengikuti pelatihan. 2) Mengukur pemahaman dan pencapaian kegiatan pelatihan ini dengan memberikan pertanyaan yang sama pada akhir pelatihan; 3) Mengukur minat peserta dalam memanfaatkan media online dalam memasarkan produk yang dihasilkan, dengan cara memberikan latihan di dalam membuat iklan kerajinan berbahan anyam mendong dan memasukkannya kedalam media sosial website sebagai pemasaran.

\section{PEMBAHASAN}

Pelatihan pemanfaaatan website pemasaran dilakukan dengan memberikan strategi pemasaran kepada mitra untuk menembus pasar modern melalui internet marketing pembuatan website. Pada kegiatan ini dilakukan dengan pembuatan blogspot untuk masing-masing UKM mitra guna meningkatkan jangkauan pemasaran. Pemasaran produk secara online saat ini banyak digunakan oleh produsen untuk memasarkan dan memperkenakan produknya ke kalangan masyarakat yang luas sehingga dapat meningkatkan nilai jualnya.

Peserta pelatihan sangat antusias dan semangat untuk mengikuti kegiatan yang dibuktikan dengan datang tepat waktu. Antusiasme juga terlihat dalam mendengarkan penjelasan narasumber dan banyaknya pertanyaan yang diajukan seputar materi yang diberikan menambah efektif dan hidup kegiatan pelaksanaan pelatihan ini. Kegiatan pelatihan ini dilakukan dalam tiga sesi dan diakhiri dengan sesi tanya jawab. Sesi pertama yaitu brainstorming, sesi kedua dan ketiga pemberian materi oleh narasumber dan diakhir dengan kegiatan tanya jawab.

Sebelum pelaksanaan pelatihan dimulai, tim pengabdian memberikan pertanyaan berupa pre-test untuk mengetahui sejauh mana pengetahuan dan pemahaman peserta dalam dunia usaha melalui pemanfaatan media online. Jawaban pre-test dari peserta rata-rata belum ada yang menjalankan bisnis dengan online dan pengetahuan serta pemahamannya dalam pemasaran melalui online hanya $66 \%$.

Materi awal pelatihan adalah brainstorming mengenai langkah-langkah awal dan tips-tips untuk memulai bisnis, dan materi mengenai internet. Kedua, materi yang disampaikan berkaitan dengan pemasaran produk dengan media online melalui website. Ketiga, pemanfaatan media online melalui website dalam melakukan pemasaran. Sesi terakhir adalah tanya jawab. Peserta secara aktif mengajukan pertanyaan yang berkaitan dengan media online mulai dari kelebihan dan kelemahan melakukan pemasaran online, 
kendala dalam melakukan jual beli online, dan bagaimana cara mencari kalimat pemasaran. Setelah tanya jawab selesai, pemateri memberikan post-test untuk mengukur tingkat penerimaan dan pemahaman peserta selama mengikuti kegiatan pelatihan. Sedangkan hasil post-test yaitu, adanya peningkatan pengetahuan dan pemahaman pelaku usaha sebesar 95\% dalam memanfaatkan penggunaan media online untuk melakukan promosi kerajinan, peserta juga mengetahui tips dan trik pemanfaatan media online untuk melakukan pemasaran produk dan mendapatkan pengetahuan dalam pengelolaan website pemasaran anyam mendong. Selain itu, peserta pelatihan mendapatkan sertifikat sebagai bukti sudah melakukan pelatihan pemasaran berbasis website.

\section{KESIMPULAN}

Pelatihan pemanfaatan website pemasaran membuat peserta antusias dan semangat dalam mengikuti kegiatan tersebut dan membuat peserta mampu mengoperasikan website yang menjembatani pelaku UKM untuk mempromosikan produk kerajinan usaha anyam mendong. Peserta pun memperoleh informasi mengenai trik dan kiat-kiat dalam memanfatkan pemasaran berbasis online. Luaran lainnya adalah sertifikat pelatihan website bagi pelaku anyam mendong. Luaran ini mendukung program pemerintah untuk terus berupaya meningkatkan kualitas masyarakat dalam hal pemasaran produk UKM dalam menghadapi MEA 2015. Selain itu, pelatihan ini dapat meningkatkan pengetahuan dan pemahaman peserta didalam menggunakan website pemasaran.

Hasil akhir berupa website yang diharapakan tidak hanya berhenti setelah program pelatihan, melainkan tim pengabdian akan melakukan pendampingan hasil pelatihan di dalam memasarkan produk-produk UKM anyam mendong melalui website pemasaran. Pendampingan tersebut dilakukan secara kontinu pada aktivasi website UKM dan perluasan pasarnya. Pendampingan ini bersifat memberdayakan sehingga UKM dituntut mandiri dalam berusaha untuk kemajuannya kelak.

\section{UCAPAN TERIMA KASIH}

Penulis mengucapkan terima kasih kepada DRPM Kementerian Ristekdikti yang telah memberikan dana Hibah PKM (Pengabdian Kepada Masyarakat) pada tahun 2018 dan telah mendukung serta mensukseskan kegiatan pengabdian ini dan kepada LPM (Lembaga Pengabdian Masyarakat) Universitas Pasundan yang telah mendukung dan memberikan motivasi untuk terus maju di dalam kegiatan pengabdian masyarakat. 


\section{DAFTAR PUSTAKA}

Adiono, Agung. (2011). Peran E-commerce untuk meningkatkan daya saing UKM. Bandung. STIE-INABA.

Chabib, dkk. (2016). Pemberdayaan Dan Pengembangan Ukm Sebagai Penggerak Ekonomi Desa (Desa Harjobinangun, Pakem, Sleman, Di Yogyakarta). AJIE (Asian Journal of Innovation and Entrepreneurship), Vol. 01(3), 203-209.

Irrubai, M. L. (2016). Strategi Labeling, Packaging dan Marketing Produk Hasil Industri Rumah Tangga. Social Science Education Journal, 3(1), 17-26.

Radjab, dkk. (2017). Prosiding Seminar Hasil Pengabdian Kepada Masyarakat. Unit Penelitian dan Pengabdian kepada Masyarakat Politeknik Negeri Ujung Pandang Makassar.

Sutanto, Supriyanto, Purwatiningtyas. (2015). Penerapan E-Commerce Berbasis Cms Dan Seo Untuk Toko On-Line Umkm. Abdimas. Vol. 19(2). 